\title{
A conceptual framework for land use and metro infrastructure
}

1 Nathan Darroch MA

PhD Student, Centre for Transport Research, University of Aberdeen, Aberdeen, UK (corresponding author: r01nd14@abdn.ac.uk)

2 Mark Beecroft BA, PhD

Lecturer, Centre for Transport Research, University of Aberdeen, Aberdeen, UK
3 John D. Nelson BA, PhD, PGCE, FCIHT, FRGS

Professor of Transport Studies, Centre for Transport Research University of Aberdeen, Aberdeen, UK
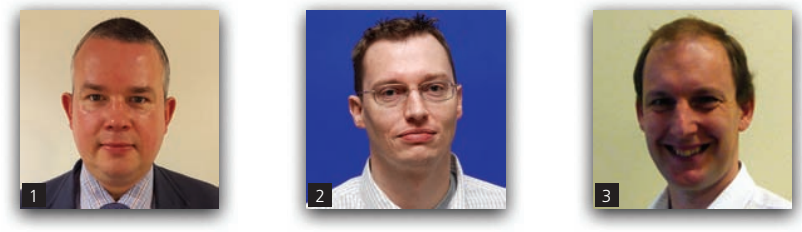

The continued urbanisation of the world's population generates pressures for the greater use of urban space. Where underground metro infrastructure is present within the urban environment, interfaces with private property at the surface and subsurface levels can raise issues from both engineering and legal perspectives. This paper introduces a conceptual framework for describing three principal interfaces identified as presence, property and protection. These three interfaces are interconnected and interdependent, each having three subinterfaces. The conceptual framework provides a way to determine these interfaces. The paper presents a proof-of-concept case study based on the Glasgow subway. It concludes that while the three overriding principal interfaces within the conceptual framework are applicable to any one metro system, not all subinterfaces may be.

\section{Introduction}

In 2014, the Department of Economic and Social Affairs of the UN-published World Urbanization Prospects (Department of Economic and Social Affairs, 2014). The report shows that 54\% of the world's population live in urban areas. By 2050, the projections anticipate that $66 \%$ of the world's population will be urban dwellers. This requires greater attention to sustainable development with facilities for the population to live, work, relax and travel within, to and from these urban areas. The requirement for alternatives to use of airspace and land space within already densely developed cities is driving calls for the use of underground urban space (UUS) under buildings or highways, not just for foundations but also as additional functional space (Bobylev, 2009; Cui et al., 2013; Durmisevic, 1999; Hunt et al., 2016; Japan Tunnelling Association et al., 2000). A significant body of work has been produced on such topics, with calls for better urban planning to create sustainable cities and, in some instances, governmental action to control use of UUS, such as in Japan, Finland and Sweden, among others (Bobylev, 2009, 2010; Hunt et al., 2016; Li et al., 2013; Sterling et al., 2012; Working Group No. 4, International Tunnelling Association, 2000). This approach to sustainable urban development requires coordinated planning at both the ground and UUS levels to be future-proofed (Bobylev, 2009; He et al., 2012; Japan Tunnelling Association et al., 2000). To date, it appears that few published works consider the long-term physical and legal interfaces of engineered underground infrastructure with its environment (Barker, 1991). This is despite physical and legal interfaces influencing how UUS and surface land space or airspace can be utilised where there are multiple property interests within one plot of land.

Through evidence derived from the lead author's professional experience as a land and vesting engineer for London Underground, undertaking legal and historical research into land and asset ownership, rights and responsibilities, and case study research relating to the Glasgow subway, this paper explores some potential long-term physical and legal effects of existing underground metro infrastructure on the built environment, in that metro infrastructure directly and indirectly limits and influences what redevelopment can be undertaken near it. The paper focuses on what enables the metro's presence, such as legislation governing land acquisition and disposal of surplus land; what the interfaces are between engineered underground infrastructure and private property, at the ground and subsoil levels; and the need to appreciate what protection the metro infrastructure has from surface or UUS development. A conceptual framework is presented to suggest a means of identifying and understanding these interfaces. It is anticipated that the conceptual framework will be just as applicable to other types of transport 
infrastructure, whether linear or nodal, due to the fact that infrastructure requires a clear definition of ownership, rights and responsibilities where there are multiple interested parties.

The benefits derived from the development of the conceptual framework are not wholly hypothetical in nature; the work has a practical application and relevance to infrastructure and construction engineers, town and transport planners and legal professionals. This practical application is demonstrated by a rare incident north of Old Street London Underground and Network Rail station, London in 2013, and the subsequent report of the British Railway Accident Investigation Branch (2014). This incident saw a flight auger penetrate a 16-feet-dia. (4.8-m-dia.) tube tunnel owned and maintained by Network Rail, the auger penetration occurring during the redevelopment of the surface property above. A cause of this incident, which saw the suspension of railway services on the line, was that neither the property owner, their solicitors undertaking the conveyancing searches or the workers on-site had fully appreciated 'the significance of an entry on the Land Registry Property Register, relating to the tunnels presence', nor had the appropriate bodies been contacted to determine the presence of the tunnels (Railway Accident Investigation Branch, 2014). The effect of such an oversight had the possibility of causing serious injury or death to passengers and staff on the railway beneath. Had the existing legal documents relating to the presence of this physical infrastructure been understood, and discussions held with Network Rail prior to starting works, this incident should not have occurred.

\section{The conceptual framework}

It has been possible to determine that metro infrastructure not only has a physical presence affecting the built environment (Devriendt et al., 2010; Perry, 2014; Simpson and Vardanega, 2014) but also a statutory and legal presence. (Defining 'statutory' as meaning that the metro has a right to be present within its environment through its specific enabling legislation and that it must accommodate the statutory rights of other parties, such as utility providers and other transport organisations, and 'legal' as being through contractual agreements for acquisition and disposal of land by the metro company or third parties, or for a right of the metro infrastructure to be located within the land of another party through easements or servitudes.) This has been arrived at through $(a)$ the professional experience of the principal author, outlined earlier; $(b)$ the report by the Railway Accident Investigation Branch in 2014; (c) through a survey by way of the Community of Metros; and $(d)$ from a review of guidance for working near metro infrastructure of three metro organisations (Crossrail, 2016; London Underground, 2015; MTR, 2014; TfL, 2016; TfL Visual Services, 2016).

These can be grouped into three principal interfaces between urban underground metro infrastructure and private property, identified as

presence
property
protection.
While the research reported here focuses solely on existing urban underground metros in tunnel or open cutting, it is anticipated that the findings will be just as applicable to highways and main line railways as it is to metros, each using tunnels in urban environments to minimise their effect on the built environment. This is because of the similar legislation and construction methods among these forms of transport. This is exemplified by the northbound Blackwall highway tunnel, passing under the River Thames in London, and its authorising act of 1887 (Thames Tunnel (Blackwall) Act 1887, 1887). This act incorporates the Land Clauses Consolidation Act 1845 (1845) and its subsequent amendments, as do main line (Network Rail) and underground railway (London) authorising acts in England and Wales, with Scotland having the Land Clauses Consolidation (Scotland) Act 1845 (1845) applicable to the Glasgow subway and national rail in Scotland.

Figure 1 shows the conceptual framework with the three principal interfaces developed to show that each has an effect on one another and that each is interdependent, as shown by the arrows in the diagram. Without one principal interface, there will not or would not be any need for the others.

Presence is the controlling interface. It incorporates the three subinterfaces of legislation, physical and future-proofing. It represents what allows the metro to be within the urban realm, what is actually within or on the ground or within structures above and below ground and that these interfaces need to be accommodated by parties external to the metro organisation, such as landowners and developers, to ensure their sustainability.

- Legislation - Legislation enables, governs and may manage the interface between the metro and private properties. To build metro infrastructure, governmental authorisation is required, whether locally or nationally (Sterling et al., 2012). It allows the physical construction of the metro and land acquisition, whether compulsorily or through an agreement; it outlines how construction works will be undertaken and the requirements for and responsibilities of the metro organisation to adjoining land and asset owners and its potential rights, such as the right of protection of the metro, and vice versa.

- Physical - Without physical infrastructure, there would be no metro. This physical infrastructure is not just the tunnels, but also ventilation passages and shafts, substations, station entrances, ticket halls and so on. Any of these may be incorporated within or adjacent to the subsoil, land space and airspace or buildings of another party (Baker, 1885). The method of construction of the metro and the strata through which it passes not only affects adjacent land and buildings but can also be affected by redevelopment of that land and those buildings (Devriendt et al., 2010; Glass and Stones, 2000; Macklin and Yeow, 2004; Measor and Williams, 1962; Perry, 2014; Simpson and Vardanega, 2014). Therefore, the presence of the metro infrastructure must be clearly understood and accommodated (Zhang et al., 2013; Zhigouo et al., 2013). Figure 2 shows the site of Kelvinhall station on 


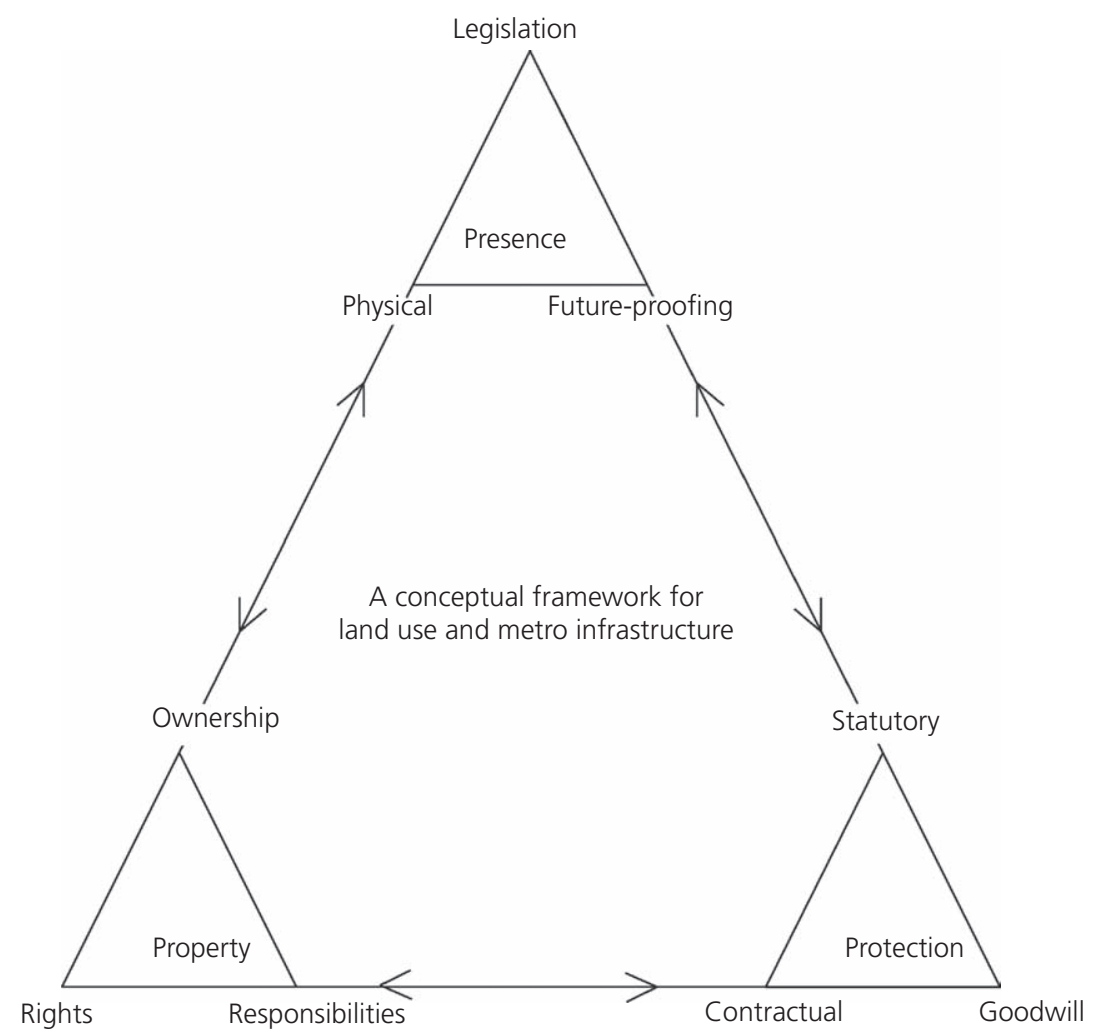

Figure 1. Conceptual framework with the three principal interfaces developed to show that each has an effect on one another and that each is interdependent, as shown by the arrows in the diagram

the Glasgow subway. It is in open cutting with a glass roof, with the surrounding Strathclyde Partnership for Transport (SPT)-owned land undeveloped. The design of the station

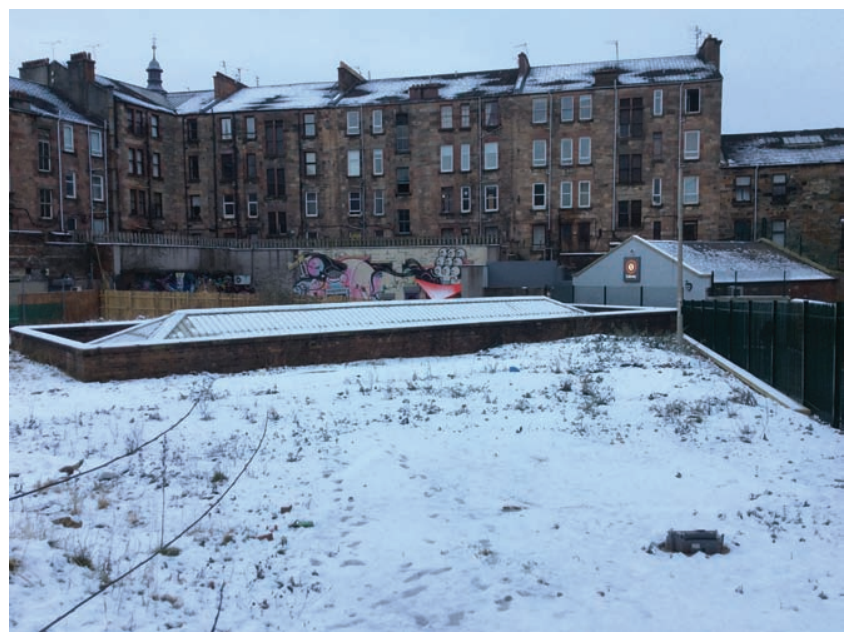

Figure 2. Site of Kelvinhall station on the Glasgow subway. It is in open cutting with a glass roof, with the surrounding SPT-owned land undeveloped would require any future development of this site to accommodate the presence of the station from physical and legal perspectives, physically ensuring the long-term presence and operability of the engineered structures while seeing some acquisition of the land, subsoil and airspace above and around it. A legal means of ensuring the safe long-term presence of those engineered assets would also be required.

- Future-proofing - To ensure proactively the continued safe presence of the metro infrastructure, some form of futureproofing may have been imposed. Future-proofing in this instance is the assurance that the presence of the metro infrastructure will be sustainable into the future. This can be through incorporation of the presence of the metro within urban master plans, with a requirement for planning authorities to consult with the metro organisation through the planning process when redevelopment of land and buildings is planned, or through safeguarding, such as with Crossrail (2016). Alternatively, the metro may have been granted statutory powers to take more land or subsoil than is physically required for its structures either by retaining it or disposing of it with restrictive covenants imposed on the land, through property rights, thus future-proofing the presence of the metro (Crossrail, 2016; Darroch, 2014). These measures allow proactive protection of the interests of the metro 
Infrastructure Asset Management

Volume 3 Issue 4
A conceptual framework for land use and

metro infrastructure

Darroch, Beecroft and Nelson organisation at the proposal, rather than the construction, stage of urban redevelopment (Li et al., 2013; Rönkä et al., 1998).

Property is the ownership, rights and responsibilities of the metro organisation and the private landowner. It is dependent on the legal presence of the metro within or near the land of another party. Property has three subinterfaces: ownership, rights and protection.

- Ownership - Ownership of land can be difficult to determine; it is not physical in itself, but it does refer to physical or material objects such as land or buildings. The actual boundaries, however, are only in legal documentation, such as conveyance or land transfer agreements, or through understanding of long-term use. Ownership of metro infrastructure is linear and nodal and can relate to physical infrastructure, physical infrastructure and land, or even just airspace above or within land or buildings. For example, where a metro company has an easement (or servitude in Scotland) through the lands of other parties, the metro organisation will generally own only the actual materials for its infrastructure (tunnels etc.). It does not own the land around, or airspace within, its tunnels. It only has an agreement to use it from the landowner, having bought or taken this right. This was common for early 'tube' railways in the UK (Darroch, 2012). For a station site, such as that at Kelvinhall, the company constructing the underground metro may buy the whole land it requires for the station, not just the subsoil, but everything above and below. It may also have been required to buy additional land it did not require for the physical presence of that metro infrastructure. This was common on the subsurface railways of London (Darroch, 2014).

- Rights - Rights are paramount to the metro organisation and the owner/s of adjacent land, property and assets, whether the metro is present through an easement or servitude or through outright land or subsoil ownership. Each party has a right to be present and to use their land or infrastructure as they see fit, as long as this use does not unreasonably and adversely affect others. With regard to metros, the right of presence and use of the land is statutory and often subject to legal agreement. For example, Figure 3 shows the street entrance to Kelvinhall station. The entrance passageway is owned by SPT, but the remainder of the building belongs to other parties. Should the building be intended for demolition and reconstruction, then SPT's right of use for entry to the station would need to be maintained.

- Responsibilities - Responsibilities are the effect of the presence of the metro infrastructure on its environment. For example, the presence of underground metro infrastructure must facilitate the safe presence of buildings or highways above ground. This is achieved by the subsurface infrastructure giving support to the surface infrastructure (Baker, 1885; Silva and Church, 2005). It is therefore the responsibility of the metro organisation to ensure that its assets are fit for purpose, not just for operating a rapid transit

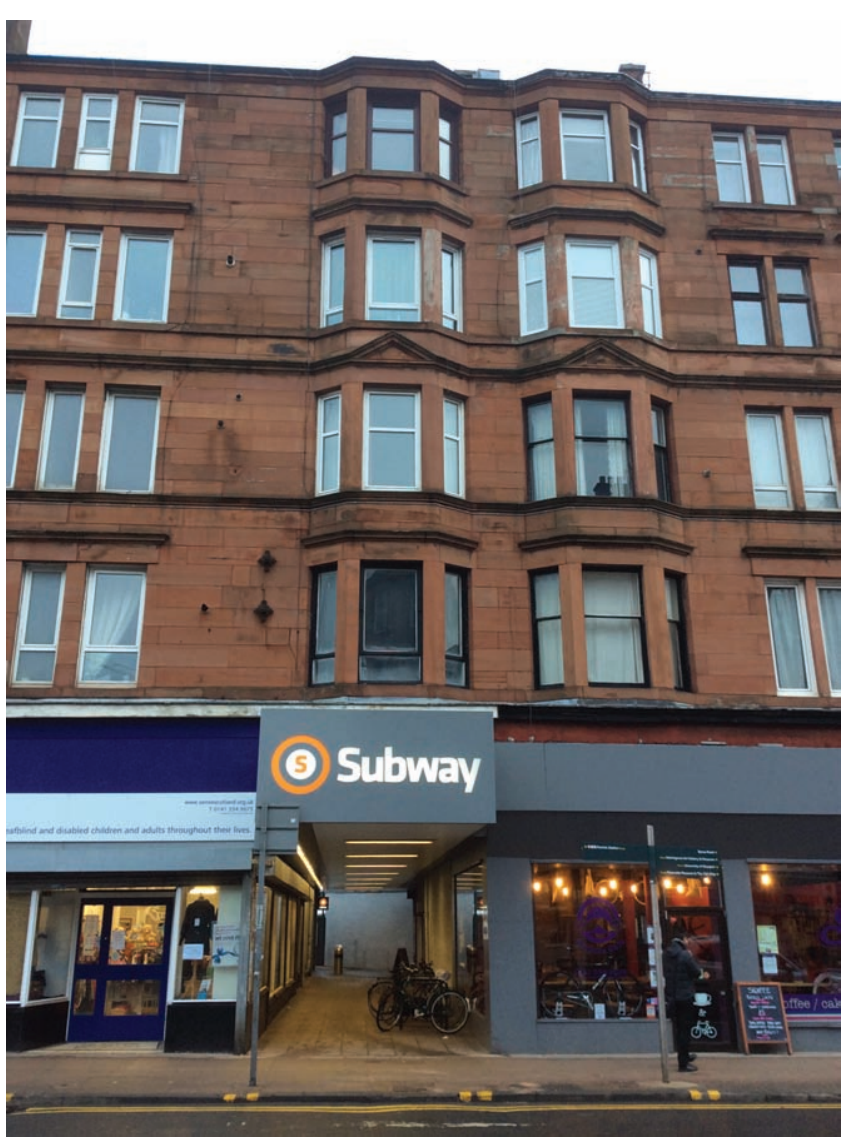

Figure 3. Access passage to Kelvinhall subway station ticket office and the station through a tenement building, the subway retaining ownership of the airspace within the tenement block

system but also for ensuring the safe presence of other urban infrastructure. Equally, the surface developer, or the mover of an abnormal load (a road vehicle with a weight exceeding $40 \mathrm{t}$ ) over the tunnel or structure, has a responsibility to not adversely affect or damage that underground infrastructure (Health and Safety at Work etc. Act 1974, 1974; HMG, 2015a; Silva and Church, 2005). So it is advantageous for that developer/haulier to open communication with the metro organisation at the planning and design stages for their project, or for the haulage company to notify the metro organisation of their intended movement before making that movement. This can lead to the metro organisation and the developer/haulier working together to ensure the appropriate knowledge and understanding of the relationship between the metro infrastructure and the redevelopment or potential weight restrictions on the structures.

Protection is an essential requirement of the metro's presence in an urban environment (Zhang et al., 2013). It can be proactive, in that it can be applied at early stages of property development (through future-proofing methods as outlined earlier), or reactive, in being undertaken once designs for a proposed development 
have been drawn up. Protection has three subinterfaces: contractual, goodwill and statutory.

- Contractual - A contract is a binding agreement between a landowner, or a developer, and the metro organisation. For example, where the metro organisation has sold surplus land for redevelopment, it may have imposed restrictions or obligations on the land, known as covenants, within the conveyance. These proactive means of protection are imposed on the land until the metro agrees to remove them; they can therefore last in perpetuity. These may include a requirement for the purchaser and their successors in title to provide designs, demolition and construction methodologies and ground movement calculations to the metro company's engineer for approval; a restriction on the use of the land, perhaps limiting the height and weight of buildings; or even the outright prohibition of development of that land.

- Goodwill - Due to changes in practice relating to land and subsoil acquisition and disposal, whether through legislation or otherwise, contractual protection may not exist. In such instances, the landowner/developer is not contractually required to discuss with the metro organisation the mitigation of risks to metro assets. Therefore, protection of that existing infrastructure is through the goodwill of the landowner/ developer contacting the metro organisation to discuss the proposed works and seeking guidance from the metro organisation. Contractual agreement may then be met once these discussions are opened, but this would be responsive rather than proactive.

- Statutory - Protection is the most beneficial means of protecting metro infrastructure. Through specific legislation, as used in Nordic countries such as Finland and Sweden, and in Japan, where the metros are of newer construction than those in the UK, landowners/developers are obliged to follow UUS regulation on the use of subsoil (Working Group No. 4, International Tunnelling Association, 2000). Users of UUS are consulted on changes to surface land use and thus are able to open discussions with planning bodies and landowners/ developers for the use of the and thus protect their presence. In the UK, there is no such statutory protection on metro infrastructure (Department for Communities and Local Government, 2014; Railway Accident Investigation Branch, 2014). Legislation and regulations such as the Party Wall Act 1996 (1996) and the Construction (Design and Management) Regulations 2015 (HMG, 2015a) do not wholly ensure that a property owner or developer will check for, or militate against, adverse effects to metro infrastructure (Department for Communities and Local Government, 2016; HMG, 2015a). Following the Old Street incident (outlined earlier), amendments to the Town and Country Planning Act 1990 (1990) in England have seen some moves towards statutory consultation with railway infrastructure managers by local planning authorities. However, these changes are only for planning authorities to consult those organisations (London Underground, Network Rail, heritage or other railway systems) with railway infrastructure in England on planning applications within $10 \mathrm{~m}$ of railway land (The Town and Country Planning (Development Management Procedure) (England) Order 2015 (HMG, 2015b)). The responses provided by the railway infrastructure bodies do not have to be accommodated within planning decisions, however. Therefore, there is still no effective statutory proactive protection of the infrastructure. Nor does this amendment apply to Wales or Scotland, which would be relevant to main line railway tunnels.

\section{Proof-of-concept study: Glasgow subway}

To determine if the conceptual framework is applicable outside of the London scenario and if it has potential relevance to metros internationally, a proof-of-concept study was undertaken using the Glasgow subway. There were a number of reasons for this choice

- similarities but ample differences physically and legally to the London network

- a common language, where it was essential to start with a network where technical and legal terms could be clearly understood

- familiarity of the researchers with the system from practical experience as users and with knowledge of that urban environment

- availability of primary and secondary sources of information relating to the system.

The study began in November 2014 with a desktop review of primary and secondary sources, such as relevant legislation, historic mapping, satellite imagery, journal articles and books published on the subway. This led to the formulation of specific questions relating to the interfaces between engineered and legal infrastructure and private property, to be put to a semistructured group interview of members of SPT. Those present in a meeting with them at the Broomloan depot, Glasgow in January 2015 included the project engineer, the senior transport planner and the senior legal advisor. In addition, site visits to stations and locations where the tunnels passed under land and property were also undertaken around the whole of the subway network to identify first hand the relationship between the subway and its environment. Inspection of the physical interfaces of the metro with its urban environment enabled a clearer understanding of the interfaces outlined in the conceptual framework.

\section{Glasgow subway overview}

Construction of the circular twin tunnel route of the subway, wholly in bored or mined tunnel or covered way (top-down construction with an arch over the void to form a tunnel), began in 1891 and was completed by 1896, with 15 stations along its nearly $6 \cdot 5$-mile-long $(10 \cdot 5$-km-long) alignment. Due to its track gauge of 4 feet $(1.21 \mathrm{~m})$, the tunnels' diameter is generally 11 feet $(3.35 \mathrm{~m})$. Station tunnels use single island platforms, side platforms and in a few instances one side and one island platform. The station tunnels were formed or reformed in the 1970s, through cut-and-cover construction between retaining walls or 
with an arch over the void (Shipway, 1996; Stewart, 1895). Most station sites at the ground level today are undeveloped apart from surface buildings for subway purposes, such as ticket halls and substations. This was an effect of a 1970s' reconstruction programme which saw the general demolition of tenement blocks by the Glasgow City Council and the need for new station facilities to replace those that had been demolished along with the tenement buildings within which ticket halls had been incorporated (Anderson, 2014: p. 69; Wright and Maclean, 1997). During this period, the subway was modernised, seeing changes made to stations, including land ownership at the ground level. In 2014, 12.95 million passengers used the subway according to newspaper Glasgow Herald (McArdle, 2015).

\section{Application of the conceptual framework to Glasgow subway}

To determine the practical applicability of the conceptual framework to the Glasgow subway, it was necessary to consider each of the interfaces and their associated subinterfaces within their own context with the available data from the SPT semistructured interview and primary and secondary sources.

\section{Presence}

\section{Legislation}

Authorisation for the construction of the subway was granted by the Glasgow District Subway Act 1890 (1890). This act incorporated the Land Clauses Consolidation (Scotland) Act 1845 (1845), which specified the rights and obligations of a railway company and landowner in Scotland for the acquisition and disposal of land. In the subway's instance, the acts allowed the acquisition of subsoil and lands for its undertaking through compulsory purchase, servitude (a right over the property of another, an easement in England) or agreement with the landowner. Where the subway passed under a public highway, there was no need for purchase of servitude or ownership, the act granting statutory use of that subsoil. To enable the 1970s' modernisation of the subway, subsequent legislation was passed enabling the compulsory acquisition of land and rights (Greater Glasgow Passenger Transport Order Confirmation Act 1975, 1975). This resulted in today's ownership of surface land above stations by SPT.

\section{Physical}

Figure 4 shows the typical alignments of the subway, whether under highway, property or open space, based on a drawing in Shipway's (1996) paper. While there are few additional surface interfaces for the metro, beyond station buildings for station functions, the form of construction of the actual tunnels is important and must be accommodated. This is in particular the case where the subway is located within soft strata, such as sand and gravel or clay south of the River Clyde, rather than rock, which is predominant north of the River Clyde (Shipway, 1996). In soft subsoil, UUS use is much more likely whether for basement additions to existing property or for new development with deeper (piled) foundations, both of which would increase the interface between the subway and private property (Bobylev, 2009).

\section{Future-proofing}

While there was an opportunity for subway owners when selling surplus lands to impose covenants on property to safeguard the subway's physical and legal interfaces with property, it appears that there was little effort to do so. The same lack of foresight affected the 1975 legislation, which allowed the Greater Glasgow Passenger Transport Executive to acquire additional lands for its works. However, as that act focused predominantly on the acquisition of land for the subway works, this is not surprising. During the semistructured interview and discussion with SPT, it was highlighted that any future land disposals above stations owned by that body, whether leased or sold for development, will see the imposition of covenants for protection of the subway.

\section{Property}

Ownership

Through the semistructured interview and discussion with SPT, it became apparent that most land and subsoil acquisition was through agreement for servitude, although some outright ownership acquisition was undertaken. Over subsequent years, land acquired outright was sold, leaving the railway with servitudes under private property. Where access to the subway was through a tenement building (as shown in Figure 3), the subway company retained ownership of the airspace within the tenement block used for the ticket office and passage to the station proper. With the 1970s' modernisation and demolition of surrounding buildings, the subway acquired outright ownership of land above its underground stations with the addition of purpose-built surface buildings to replace the original demolished tenement building entrances.

\section{Rights}

Due to the servitude of the subway under private property, the SPT has a right to use only the subsoil under that private property. Despite the obligation for SPT to operate a safe railway, it cannot enforce any protection for itself from external agencies. In this instance, the landowner has the most benefit, having a right of support from the subway infrastructure and the right to use their land as they desire. This is within the town planning constraints imposed by the local authority, which do not accommodate the need for, or the facility to, ensure the safe presence of the subway. There is therefore a potential risk to the subway that surface works could affect the presence of the railway, even inadvertently. As mentioned earlier, such a risk is greater south of the River Clyde, where the stratum is softer than that on the north side, where it is rock and unlikely to see UUS use, due to the benefits the rock stratum gives to building support and the costs that excavating rock stratum incurs (Hood, 2004: p. 84).

\section{Responsibilities}

Despite the lack of ownership of sub-soil beneath private property and the right of the landowner to use their land, SPT and the landowner still have the responsibility to accommodate each other's needs and the needs of the subway's 12.95 million passengers per year. Failure to do so could see financial penalties 


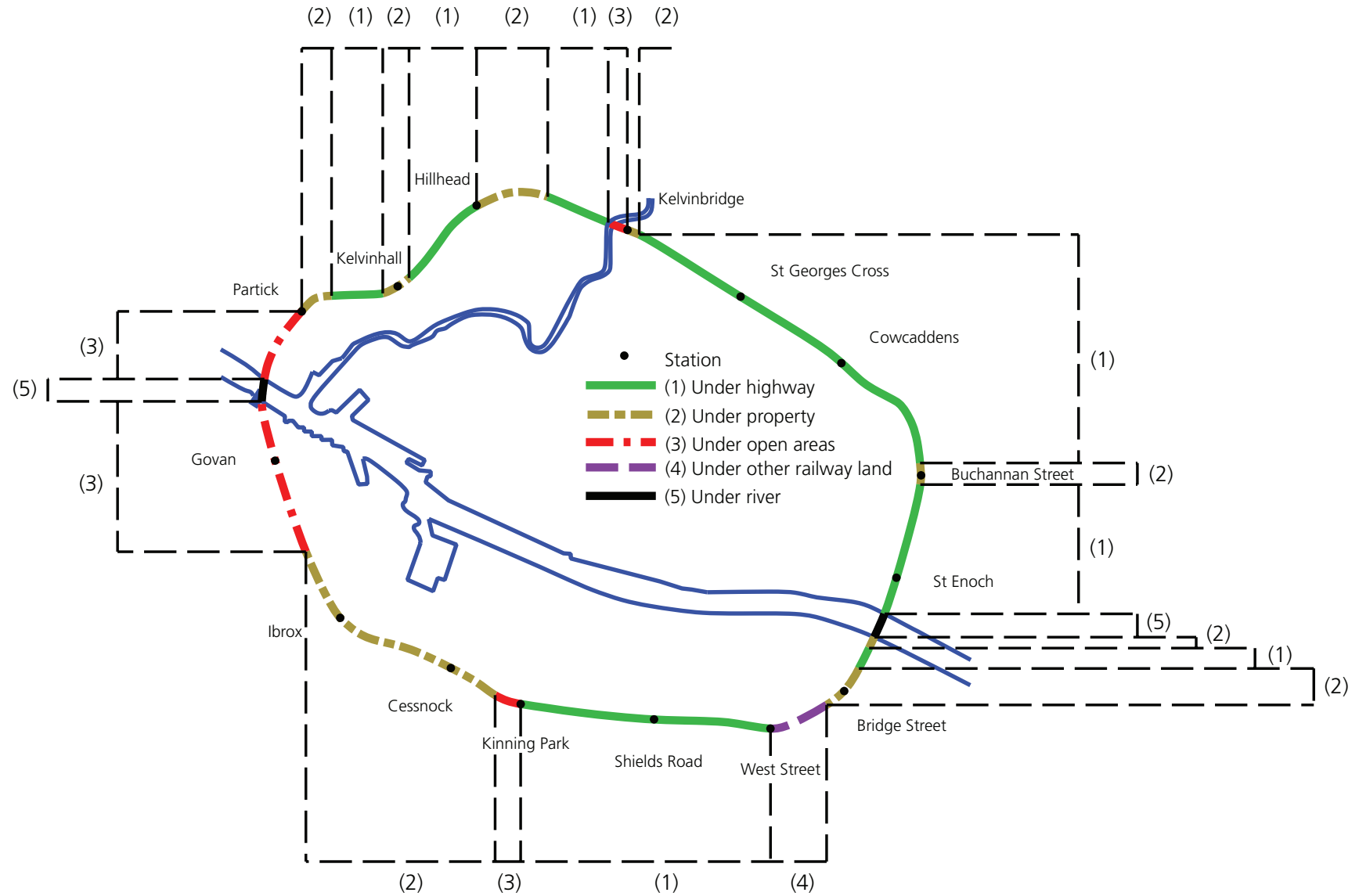

Figure 4. Typical alignments of the subway, whether under highway, property or open space, based on a drawing in

Shipway's (1996) paper

on any party that was to cause short- or long-term disruption or damage to the safe operation and presence of the railway and its related infrastructure.

\section{Protection}

\section{Contractual}

As highlighted earlier, contractual protection of the railway has generally not been imposed on lands sold by the subway owners in the past. During the semistructured interview, the members of SPT were able to explain the practical effects of such contractual protection with illustration from the extension of the Buchanan Street shopping centre, at the centre of the city. At this location, a pedestrian subway containing a moving walkway, both owned by SPT, links the subway station to Queen Street main line station (owned by Network Rail). Not only will the shopping centre works affect the safe operation of the SPT infrastructure, but they will also result in improvements to the existing infrastructure and additional features, all of which have been agreed between SPT and the Buchanan Partnership as part of the shopping centre works. That way, the user of the subway gains protection not only from building works but also for the future with improved facilities (SPT, 2015).

\section{Goodwill}

Due to the lack of a contractual right to protection for the presence of the subway, the goodwill of a landowner/developer is essential. It was highlighted through the discussion with SPT that should it be necessary to protect the infrastructure from adjacent development, it would be necessary to take out an injunction for works to cease. However, it was stated that this is the absolute last resort, the preferable option being to discuss with the landowner/developer their proposals at the design stage so that the safe presence of the subway could be accommodated. This is also a reactive, rather than the more beneficial proactive, method of dealing with interfaces between the metro and third-party development.

\section{Statutory}

As described earlier, current legislation and regulations do not allow for specific statutory obligation for a landowner/developer to discuss proposals for use of land adjacent to or above the metro with the metro organisation.

\section{Findings and conclusion}

This paper has highlighted that from the research undertaken so far, while there is a significant body of work produced on future 
potential uses of UUS and in some instances governmental action to control use of subsoil, few published works consider the longterm physical and legal interfaces of engineered underground infrastructure within its environment. These physical and legal interfaces influence how urban environments can be utilised where there are property interests of two or more parties in one plot of land. For example, the placement of building foundations or even the buildings themselves can and will be affected by the presence, property and means of protection of the metro infrastructure.

A conceptual framework influenced by the lead author's first-hand professional experience of the London Underground relationship between engineered and legal infrastructure and private property and utilities; an initial survey of member organisations of the Community of Metros; the findings of a UK Railway Accident Investigation Branch's (2014) report of the reasons why a flight auger penetrated a deep tube tunnel in London; and a semistructured group interview with representatives from SPT have therefore been presented. The aim of the framework is to identify and explain the three principal interfaces between underground metros and private property within an urban environment, with subinterfaces clarifying what these interfaces are or could be. These interfaces and subinterfaces are identified as

v presence - legislation allowing the physical presence of metro infrastructure and enabling the future-proofing of that infrastructure

- property - aspects of land ownership, rights and responsibilities of the metro and landowners/developers

- protection - whether contractual, goodwill or statutory.

To determine the practical applicability of the conceptual framework, the interfaces of the Glasgow subway were researched and have been presented as a proof-of-concept study. The findings from this study show that the three principals of interface apply to that metro system as they do with London. There are, however, instances where the subinterfaces are not applicable due to their non-existence. For example, the specific statutory interface of protection is not applicable, as there is no statutory requirement in England or Scotland for landowners/developers to discuss their projects with the metro organisations affected. There are, however, legislation and regulations such as the Party Wall Act 1996 (1996) and the Construction (Design and Management) Regulations 2015 (HMG, 2015a), but these are reactive for the metro system, as Construction (Design and Management) Regulations 2015 particularly does not oblige the promoter of new development to engage with the metro.

From the findings of the case study, it is argued here that while not all subinterfaces may be applicable to any one metro, or even any one line of a metro system that has more than one line, there is a need for an understanding of them. While further work is being undertaken to demonstrate the applicability of the conceptual framework to London Underground, it is suggested here that the framework will be applicable to many metro systems across the world. This further research will present scenarios of London and compare these with examples of international metro infrastructure. The presence of existing underground infrastructure, whether linear or nodal, therefore requires more research and discussion when considering the development of policies to encourage sustainable cities, in particular in light of projections of the Department of Economic and Social Affairs of the UN that by $2050,66 \%$ of the world's population will live in an urban environment, with the requisite demands on land use and needs for beneficial transit systems.

\section{Acknowledgements}

Acknowledgement is extended to the members of SPT who participated in the semistructured interview for this paper and the wider research currently being undertaken. Acknowledgement is also extended to Mr Malcolm Payne, the principal infrastructure protection engineer of London Underground, for his input into this paper and the wider research currently being undertaken.

\section{REFERENCES}

Anderson K (2014) Glasgow Underground: the Glasgow District Subway. Stroud, Amberley, UK.

Baker B (1885) The Metropolitan and Metropolitan District Railways. Minutes of the Proceedings of the Institution of Civil Engineers 81(1885): 1-33, http://dx.doi.org/10.1680/imotp. 1885.21367.

Barker M (1991) Legal and administrative issues in underground space use: a preliminary survey of ITA member nations. Tunnelling and Underground Space Technology 6(2): 191-209, http://dx.doi.org/10.1016/08867798(91)90066-D.

Bobylev N (2009) Mainstreaming sustainable development into a city's master plan: a case of urban underground space use. Land Use Policy 26(4): 1128-113, http://dx.doi.org/10.1016/j. landusepol.2009.02.003.

Bobylev N (2010) Underground space in the Alexanderplatz area, Berlin: research into the quantification of urban underground space use. Tunnelling and Underground Space Technology 25(5): 495-507, http://dx.doi.org/10.1016/j.tust. 2010.02.013.

Crossrail (2016) Crossrail, Information for Developers. Crossrail, London, UK. See http://74f85f59f39b887b696fab656259048fb93837ecc0ecbcf0c557.r23.cf3.rackedn.com/ assets/library/document/c/original/crossrail_information_for_ developers_march_2016.pdf (accessed 11/03/2016).

Cui J, Allan A, Taylor AP and Lin D (2013) Underground pedestrian systems development in cities: influencing factors and implications. Tunnelling and Underground Space Technology 35: 152-160, http://dx.doi.org/10.1016/j.tust.2012. 12.009 .

Darroch N (2012) London's Deep Tube Railways: Visibly Invisible. MA thesis, University of York, York, UK. See http:// etheses.whiterose.ac.uk/3905 (accessed 21/03/2015). 
A conceptual framework for land use and

metro infrastructure

Darroch, Beecroft and Nelson
Darroch N (2014) A brief introduction to London's underground railways and land use. Journal of Transport and Land Use 7(1): 105-116, http://dx.doi.org/10.5198/jtlu. v7i1.411.

Department for Communities and Local Government (2014) Planning Application Process Improvements, Government Response to Consultation. Department for Communities and Local Government, London, UK. See https://www.gov.uk/ government/uploads/system/uploads/attachment_data/file/ 397719/150122_Planning_application_process_improvements. pdf (accessed 07/09/2016).

Department for Communities and Local Government (2016) Party Wall etc. Act 1996 Explanatory Booklet. Department for Communities and Local Government, London, UK. See https://www.gov.uk/government/uploads/system/uploads/ attachment_data/file/523010/Party_Wall_etc_Act_1996_Explanatory_Booklet.pdf> (accessed 06/09/2016).

Department of Economic and Social Affairs (2014) World Urbanization Prospects. UN, New York, NY, USA. See http:// esa.un.org/unpd/wup (accessed 29/06/2015).

Devriendt M, Doughty L, Morrison P and Pillai A (2010) Displacement of tunnels from a basement excavation in London. Proceedings of the Institution of Civil Engineers Geotechnical Engineering 163(3): 131-145, http://dx.doi.org/ 10.1680/geng.2010.163.3.131.

Durmisevic S (1999) The future of the underground space. Cities 16(4): 233-245, http://dx.doi.org/10.1016/S0264-2751(99) 00022-0.

Glasgow District Subway Act 1890 (1890) Victoria. Chapter clxii. Her Majesty's Stationery Office, London, UK.

Glass P and Stones C (2000) Construction of Westminster Station, London. Proceedings of the Institution of Civil Engineers Structures and Buildings 146(3): 237-252, http://dx.doi.org/ 10.1680/stbu.2001.146.3.237.

Greater Glasgow Passenger Transport Order Confirmation Act 1975 (1975) Chapter xxvi. Her Majesty's Stationery Office, London, UK.

He L, Song Y, Dai S and Durbak K (2012) Quantitative research on the capacity of urban underground space - the case of Shanghai, China. Tunnelling and Underground Space Technology 32: 168-179, http://dx.doi.org/10.1016/j.tust.2012. 06.008 .

Health and Safety at Work etc. Act 1974 (1974) Chapter 27. Her Majesty's Stationery Office, London, UK. See http://www. hse.gov.uk/legislation/hswa.htm (accessed 05/09/2016).

HMG (Her Majesty's Government) (2015a) The Construction (Design and Management) Regulations 2015. The Stationery Office, London, UK, Statutory Instrument 2015 No. 51. See http://www.hse.gov.uk/construction/cdm/2015/index.htm (accessed 05/09/2016)

HMG (2015b) The Town and Country Planning (Development Management Procedure) (England) Order 2015. The Stationery Office, London, UK, Statutory Instrument 2015 No. 595. See http://www.legislation.gov.uk/uksi/2015/595/pdfs/ uksi_20150595_en.pdf (accessed 05/09/2016).
Hood C (2004) 722 Miles: the Building of the Subways and How They Transformed New York. John Hopkins University Press, Baltimore, MD, USA.

Hunt DVL, Makana LO, Jefferson I and Rogers CDF (2016) Liveable cities and urban underground space. Tunnelling and Underground Space Technology 55: 8-20, http://dx.doi.org/10. 1016/j.tust.2015.11.015.

Japan Tunnelling Association, Takasaki $\mathrm{H}$, Chikahisa $\mathrm{H}$ and Yuasa $\mathrm{Y}$ (2000) Planning and mapping of subsurface space in Japan. Tunnelling and Underground Space Technology 15(3): 287-301, http://dx.doi.org/10.1016/S0886-7798(00)00057-2.

Land Clauses Consolidation Act 1845 (1845) Victoria. Chapter 18. Her Majesty's Stationery Office, London, UK.

Land Clauses Consolidation (Scotland) Act 1845 (1845) Victoria. Chapter 19. Her Majesty's Stationery Office, London, UK.

Li H, Parriaux A, Thalmann P and Li X (2013) An integrated planning concept for the emerging underground urbanism: Deep City Method Part 1 concept, process and application. Tunnelling and Underground Space Technology 38: 559-568, http://dx.doi.org/10.1016/j.tust.2013.04.010.

London Underground (2015) G0023 Infrastructure Protection Special Conditions for Outside Parties Working on or near the Railway. London Underground, London, UK.

Macklin SR and Yeow HC (2004) King's Cross underground station, London: geotechnical aspects. Proceedings of the Institution of Civil Engineers - Transport 157(4): 221-229, http://dx.doi.org//10.1680/tran.2004.157.4.221.

McArdle H (2015) Record passenger numbers for Glasgow Subway thanks to Games boost. Glasgow Herald, 1 May. See $\mathrm{http}: / / \mathrm{www} \cdot h e r a l d s c o t l a n d . c o m / n e w s /$ transport/recordpassenger-numbers-for-glasgow-subway-thanks-to-gamesboost.124755794 (accessed 01/07/2015).

Measor EO and Williams GJM (1962) Features in the design and construction of the Shell Centre, London. Proceedings of the Institution of Civil Engineers 21(3): 475-502, http://dx.doi.org/ 10.1680/iicep.1962.05072.

MTR (2014) Railway Protection. MTR, Hong Kong. See https:// www.mtr.com.hk/en/corporate/operations/protection_rps.html (accessed 11/03/2016).

Party Wall Act 1996 (1996) Chapter 40. Her Majesty's Stationery Office, London, UK.

Perry P (2014) Development over London Underground tunnels: No. 1 Grafton Street. Proceedings of the Institution of Civil Engineers - Structures and Buildings 167(12): 728-742, http://dx.doi.org/10.1680/stbu.11.0002.

Railway Accident Investigation Branch (2014) Penetration and Obstruction of a Tunnel between Old Street and Essex Road Stations, London, 8 March 2013. Railway Accident Investigation Branch, Derby, UK. See http://www.raib.gov.uk/ cms_resources.cfm?file=/140213_R032014_Old_Street.pdf (accessed 30/07/2014).

Rönkä K, Ritola J and Rauhala K (1998) Underground space in land use planning. Tunnelling and Underground Space Technology 13(1): 39-49, http://dx.doi.org/10.1016/S08867798(98)00029-7. 
Shipway J (1996) Centenary of the Glasgow Subway, 1896-1996. Proceedings of the Institution of Civil Engineers - Civil Engineering 114(3): 130-139, http://dx.doi.org/10.1680/icien. 1996.28621.

Silva TMD and Church DG (2005) Strengthening two London Underground covered ways. Proceedings of the Institution of Civil Engineers - Transport 158(3): 139-147, http://dx.doi. org/10.1680/tran.2005.158.3.139.

Simpson B and Vardanega P (2014) Results of monitoring at the British Library excavation. Proceedings of the Institution of Civil Engineers - Geotechnical Engineering 167(2): 99-116, http://dx.doi.org/10.1680/geng.13.00037.

SPT (Strathclyde Partnership for Transport) (2015) Big Changes at Buchanan Street Subway. SPT, Glasgow, UK. See http:// www.spt.co.uk/2015/05/big-changes-at-buchanan-streetsubway (accessed 29/06/2015).

Sterling R, Admiraal H, Parker H et al. (2012) Sustainability issues for underground space in urban areas. Proceedings of the Institution of Civil Engineers - Urban Design and Planning 165(4): 241-254, http://dx.doi.org/10.1680/udap.10.00020.

Stewart A (1895) Students' paper: The Glasgow District Subway. Minutes of the Proceedings of the Institution of Civil Engineers 122(1895): 355-362, http://dx.doi.org/10.1680/ imotp. 1895.19712.

Thames Tunnel (Blackwall) Act 1887 (1887) Victoria. Chapter clxxii. Her Majesty's Stationery Office, London, UK.
TfL (2016) Infrastructure Protection. TfL, London, UK. See https://tfl.gov.uk/info-for/urban-planning-and-construction/ infrastructure-protection (accessed 09/08/2016).

TfL Visual Services (Transport for London Visual Services) (2016) LU Infrastructure Protection. TfL, London, UK, video. See https://youtu.be/0hGoJMTBOEg (accessed 09/06/2016).

Town and Country Planning Act 1990 (1990) Chapter 8. Her Majesty's Stationery Office, London, UK.

Working Group No. 4, International Tunnelling Association (2000) Planning and mapping of underground space - an overview. Tunnelling and Underground Space Technology 15(3): 271-286, http://dx.doi.org/10.1016/S0886-7798(00) 00056-0.

Wright J and Maclean I (1997) Circles under the Clyde: a History of the Glasgow Underground. Capital Transport, London, UK.

Zhang J, Chen J, Wang J and Zhu Y (2013) Prediction of tunnel displacement induced by adjacent excavation in soft soil. Tunnelling and Underground Space Technology 36: 24-33, http://dx.doi.org/10.1016/j.tust. 2013.01.011.

Zhigouo Z, Huang M and Wang W (2013) Evaluation of deformation response for adjacent tunnels due to soil unloading in excavation engineering. Tunnelling and Underground Space Technology 38: 244-253, http://dx.doi. org/10.1016/j.tust.2013.07.002.

\section{HOW CAN YOU CONTRIBUTE?}

To discuss this paper, please submit up to 500 words to the editor at journals@ice.org.uk. Your contribution will be forwarded to the author(s) for a reply and, if considered appropriate by the editorial board, it will be published as a discussion in a future issue of the journal. 